\title{
The Impact of Human Resource Practices on Employees' Intention to Stay and Organisational Commitment in the IT Firms
}

\author{
${ }^{1}$ Amir H. Khan, ${ }^{2}$ Shravan J. Chandak, ${ }^{3}$ Param Agrawal \\ ${ }^{1,2}$ Assistant Professor, Department of Management Technology, \\ ${ }^{3}$ Student, Department of Management Technology, \\ Shri Ramdeobaba College of Engineering \& Management, Ramdeo Tekdi, Gittikhadan, Katol Road, Nagpur \\ Email:khanah@rknec.edu, chandaksj3@rknec.edu,agrawalpv@rknec.edu
}

Received: $20^{\text {th }}$ September 2018, Accepted: $11^{\text {th }}$ October 2018, Published: $31^{\text {st }}$ October 2018

\begin{abstract}
The growing body of knowledge is supporting the impact of human resource (HR) practices on employees' intention to stay and organizational commitment. The purpose of the study is to contribute in the existing knowledge by analysing the HR practices of the IT sector.

The existing literature is reviewed in the light of this topic to identify key factors affecting employees' intention to stay and their organisational commitment. Factors were identified such as employees' fit to the organisation, remuneration, training and career development practices, appraisal, reward and motivation to test the impact on employees' intention to stay and their organisational commitment. The study was conducted in different phases using quantitative methods. Snow ball and convenience sampling were used to collect the data from IT sector employees.

The present study has identified several empirically developed dimensions and also ensures the validity and reliability of these dimensions. After applying regression analysis, the impact of selected components was tested on employees' intention to stay and their commitment level towards the organisation.
\end{abstract}

\section{Keywords}

Commitment, HR Practices, Intention, Loyalty

\section{Introduction}

An immense literature has been published highlighting the association of human resource practices in commitment level and intentions of employees to stay in the organization. MacDuffie (1995) emphasized on three conditions with respect to the contribution of innovative human resource practices in the economic performance of the organization: Skills and knowledge possessed by the employee; motivation of the employees to execute this skill and knowledge with freedom; Productivity can only be achieved with such discretionary work. David E. Guest, 1997).Every organization expects outcomes from human resource practices in terms of highly committed, flexible and skilful employees (David E. Guest, 1997).

The commitment level of employees towards the organization can be measured with the help of the definition proposed by Porter and Steers (1982) mentioning that the major indicators of commitment of employees are desire to belong and willingness to do things for the organization. (David E. Guest, 1997).Therefore, it is necessary to measure impact of HR practices on employees' commitment level and intention to stay.

Janet Chew (2008) highlighted in his study the contribution of retaining committed employees in the survival of organization (Das, 2002). In view of this many organizations are trying with full potential of human resource practices to create positive environment in their organization in an attempt to develop committed employees and to retain them (Janet Chew, 2008). Janet further discussed the list of human resource practices that are contributing effective role in achieving organization goal with respect to manpower planning such as whether employees' values are good fit with the organization's values during recruitment and selection procedure; deciding equitable compensation to value the efforts of employees'; establishing mechanism for continuous training and career development. These activities are directed towards improving employees' attitude and behaviour by ensuring performance with the coherence between effective human resource practices and workplace relations (Janet Chew, 2008).

Therefore, the research paper is based on the investigation of the impact of human resource practices on employee's intention to stay and organisational commitment among the information Technology sectors' employee. The study will be helpful in providing the practical implications to the organisations to remove obsolete practices and to improve the retention and commitment level of employees.

\section{Literature Review}

Recruitment involves the identification, selection, acquisition, placing and enhancing the career of candidates suitable for the organisational need (Michael Joseph Martin, 2011).Training helps the organisations in improving the job deficiency and skill enhancement among employees to fulfil the future need of the organisations also (Janet Chew, 2008; Gold, 2001). 
Hale (2003) discussed that organisational commitment are closely associated with training and development (Michael Joseph Martin, 2011). Palmer (2006) have also highlighted organisational commitment as a characteristic of dimensions such as recruitment, selection, training and career development. Willis (2000) mentioned that better compensation helps to attract and retain talent. Janet Chew (2008) discussed that companies pay better compensation more than the market rate to retain rare talent and valuable employees.

The higher commitment level was also found among the employees who were promoted in the organisation (Gaertner and Nollen,1989; Michael Joseph Martin, 2011).Performance appraisal works as the tangible tool to evaluate the performance of employees. It contributes significantly in the organisational commitment of employees (Behery and Paton, 2008). Shahnawaz and Juyal (2006) stated that performance appraisal evaluates the performance, satisfaction and commitment level of employees.

Similarly, employees show high level of commitment and intention to stay in the organisation when their competencies, work and performance are valued and appreciated by the organisation (Davies, 2001).

\section{Methodology}

The research design and descriptive and follows quantitative research methods. The IT employees were chosen as the sample of the study and the data was collected using self-administered questionnaire as research instrument. The convenience sampling technique was used to collect data from the employee. Initially the parameters were identified using exploratory research by referring the secondary data and discussion with the experts.

\section{Questionnaire Design}

The self-administered questionnaire was designed in three inherent parts which were coded based on their dimensions. The first part presents the respondents details with respect to age, gender, previous job, career level, experience etc. The second part comprises of the human resource practices such as recruitment, selection, training, compensation and appraisal. The third part of the questionnaire included the parameters related to employee intention to stay and the commitment towards the organisation. The questionnaire was design by referring the published sources such as Ghazali et al. (2016), Aladwan et al. (2015), Daifallah Olaimat \& Bassam Awwad (2017), Michael Joseph Martin (2011). The questionnaire was designed using likert scale of 1 to 7 where 1 represents "strongly disagree" and 7 represents "strongly agree".

\section{Hypotheses}

Based on the interaction with the employees, observation and secondary data analysis, the study hypothesizes that:

H1: There is a significant impact of recruitment \& selection on intention to stay among IT employees' and their commitment towards the organisation.

H2: There is a significant impact of training on intention to stay among IT employees' and their commitment towards the organisation.

H1: There is a significant impact of compensation system of organisation on intention to stay among IT employees' and their commitment towards the organisation.

$\mathrm{H} 2$ : There is a significant impact of appraisal on intention to stay among IT employees' and their commitment towards the organisation.

\section{Result \& Discussion}

\begin{tabular}{|l|l|l|l|}
\hline Respondents' Profile & Categories & Frequency & Percentage \\
\hline Gender & Male & 73 & $78 \%$ \\
& Female & 21 & $22 \%$ \\
\hline Age & $20-30$ & 32 & $34 \%$ \\
& $31-40$ & 44 & $47 \%$ \\
& $41-50$ & 12 & $13 \%$ \\
\hline Change of job in the last 5 & 51 and above & 06 & $06 \%$ \\
years & 1 & 67 & $71 \%$ \\
& 2 & 23 & $25 \%$ \\
& 3 & 03 & $3 \%$ \\
\hline Previous Job & $>5$ & 01 & $01 \%$ \\
& IT Industry & 00 & $00 \%$ \\
\hline
\end{tabular}




\begin{tabular}{|l|l|l|l|}
\hline Education Level & Diploma & 00 & $00 \%$ \\
& Bachelor & 81 & $86 \%$ \\
& Master & 13 & $14 \%$ \\
& PhD or equivalent higher education & 00 & $00 \%$ \\
\hline Experience & 5 and Less & 26 & $28 \%$ \\
& $6-10$ & 40 & $42 \%$ \\
& $11-15$ & 18 & $19 \%$ \\
& 16 and above & 10 & $11 \%$ \\
\hline Career Level & Jr. Employee & 56 & $59 \%$ \\
& Team Leader & 18 & $19 \%$ \\
& Manager & 12 & $13 \%$ \\
& Head & 08 & $09 \%$ \\
\hline
\end{tabular}

The table shows that male constituted $78 \%$ of the sample size. Majority of the respondents belongs to the age group of 31-40. All the respondents have worked previously in the IT industry and $71 \%$ of the respondents did not change their job in the last five years.

\section{Regression}

The regression analysis test is applied to analyse the relationship between dependent and independent variables. The dependent variables such as the intention to stay and commitment of the employees are tested against the independent variables such as recruitment\& selection, training, compensation and appraisal practices of the human resource department. The null and alternate hypotheses are formed to test the relationship among the dependent and independent variables.

\begin{tabular}{|c|c|c|c|c|c|}
\hline $\begin{array}{l}\text { Dependents } \\
\text { Variables } \\
\end{array}$ & Independent Variables & $\mathbf{R}$ & R Square & Significance & $\begin{array}{l}\text { Null } \\
\text { Hypothesis }\end{array}$ \\
\hline \multirow{4}{*}{$\begin{array}{l}\text { Intention to } \\
\text { stay among IT } \\
\text { Employees }\end{array}$} & Recruitment \& Selection & \multirow{4}{*}{0.733} & \multirow{4}{*}{0.684} & \multirow{4}{*}{0.00} & \multirow{4}{*}{$\begin{array}{l}\text { Rejected for } \\
\text { all } \\
\text { dimensions }\end{array}$} \\
\hline & Training & & & & \\
\hline & Compensation System & & & & \\
\hline & Appraisal & & & & \\
\hline \multirow{4}{*}{$\begin{array}{l}\text { Commitment } \\
\text { level of IT } \\
\text { Employees }\end{array}$} & Recruitment \& Selection & \multirow{4}{*}{0.781} & \multirow{4}{*}{0.637} & \multirow{4}{*}{0.00} & \multirow{4}{*}{$\begin{array}{l}\text { Rejected for } \\
\text { all } \\
\text { dimensions }\end{array}$} \\
\hline & Training & & & & \\
\hline & Compensation System & & & & \\
\hline & Appraisal & & & & \\
\hline
\end{tabular}

The $\mathrm{R}$ and $\mathrm{R}$ square value is greater than zero that shows a linear relationship between the variables. The correlation coefficient i.e., $\mathrm{R}$ is $+0.733 \& 0.781$, which is very close to 1 . This shows a very strong correlation among variables. The coefficient of determination $\mathrm{R}$ square is $0.684 \& 0.637$. This indicates that $68 \% \& 63 \%$ of the variation in the intention of IT employees to stay in the organisation and commitment level among the IT employees are explained by the human resource practices as explained in the above table.

\section{One Sample Two Tail Z Test:}

\begin{tabular}{|c|c|c|c|c|c|}
\hline Dimensions & Mean & SD & Z-Score & P-Value & $\begin{array}{l}\text { Null } \\
\text { Hypothesis }\end{array}$ \\
\hline Recruitment \& Selection & 3.41 & 0.98 & 5.82 & 4.42E-09 & \multirow{6}{*}{$\begin{array}{l}\text { Rejected for all } \\
\text { dimensions }\end{array}$} \\
\hline Training & 2.27 & 0.79 & -6.31 & $4.32 \mathrm{E}-11$ & \\
\hline Compensation System & 2.19 & 0.82 & -6.51 & $4.11 \mathrm{E}-07$ & \\
\hline Appraisal & 2.20 & 0.80 & -6.44 & $4.27 \mathrm{E}-11$ & \\
\hline Intentions to Stay among IT Employees & 3.83 & 0.92 & 5.40 & $1.07 \mathrm{E}-03$ & \\
\hline Commitment level among IT Employees & 4.78 & 0.96 & 7.61 & $2.41 \mathrm{E}-13$ & \\
\hline
\end{tabular}

In the above table, the $\mathrm{Z}$ score values of recruitment \& selection, intensions to stay and commitment of IT employees towards the organisation are positive and are located beyond the critical region of distribution curve. The $\mathrm{p}$ values for these dimensions are also less than 0.05 , thus null hypotheses would be rejected and it can be safely concluded that the IT employees are satisfied to some extent towards such practices of human resource department of the IT organisations. Other dimensions have shown negative $\mathrm{z}$ score which represents that the employees' responses towards the dimension is vey low and also the $\mathrm{p}$ values are less than 0.05 which signifies 
that the null hypotheses would be rejected. Thus, these dimensions do not contribute in the employees' intention to stay in the organisation and their commitment.

\section{Conclusion, Implications and Recommendations}

The result of the study has validated the concept that effective human resource practices are major influencer among IT employees' belongingness towards their organisations. The study has shown that employees are more satisfied towards recruitment \& selection practices of IT organisations compared to other practices which need significant attention and refinement. The employees' intention to stay and commitment are largely dependent on the values and recognition given by the organisation to their employees. The study signifies that human resource practices should be given attention as strategic planner in the organisation as it contributes major part in the employees' intention to stay and commitment towards the organisation. The study also contributes in the current literature of human resource practices.

\section{References}

1. MacDuffie, JP. Human Resource Bundles and Manufacturing Performance: Flexible Production Systems in the World Auto Industry. Industrial Relations and Labor Review, 48:197-221, 1995.

2. David E Guest. Human resource management and performance: are view and research agenda. The International Journal of Human Resource Management, 8:3,263-276, DOI: 10.1080/095851997341630, 1997.

3. Mowday RT, Porter LW, Steers RM. Employee-Organization Linkages: The Psychology of Commitment. Absenteeism and Turnover, New York: Academic Press, 1982.

4. Janet Chew, Christopher CA, Chan. Human resource practices, organizational commitment and intention to stay. International Journal of Manpower, Vol. 29 Issue: 6, pp.503522, https://doi.org/10.1108/01437720810904194, 2008.

5. Das H. The four faces of pay: an investigation into how Canadian managers view pay. International Journal of Commerce \&Management, Vol. 12, pp. 18-41, 2002.

6. Michael Joseph Martin. Influence of Human Resource Practices on Employee Intention to Quit. PhD thesis, Virginia Polytechnic Institute and State University, Agricultural and Extension Education, July 15, 2011.

7. Hale B. Publishing models and article dates explained. Journal of Social Welfare and Family Law, Vol. 25 No. 4, pp. 3-5, 2003.

8. Palmer L. The impact of human resource management practices on employees' Commitment in the Banking Sector in Kingston.PhD thesis, Nova Southeastern University, ProQuest, Jamaica, 2006.

9. Willis C. Go for your goals. Working Woman, March, pp. 6-7, 2000.

10. Gaertner KN, Nollen SD. Career experiences, perceptions of employment practices, and psychological commitment to the organization. Human Relations, 42(11), 975-991, 1989.

11. Behery MH, Paton RA. Performance appraisal-cultural fit: organizational outcomes within the UAE. Education, Business and Society: Contemporary Middle Eastern Issues, Vol. 1 No. 1, pp. 34-49, 2008.

12. Shahnawaz MG, Juyal RC. Human resource management practices and organizational commitment in different organizations. Journal of the Indian Academy of Applied Psychology, Vol. 32 No. 3, pp. 171-178, 2006.

13. Davies R. How to boost staff retention. People Management, Vol. 7, pp. 54-6, 2001.

14. Johari J, Yean T, Adnan Z, Yahya KK, Ahmad MN. Promoting Employee Intention to Stay: Do Human Resource Management Practices Matter?. Int. Journal of Economics and Management, 6(2): 396 - 416 , 2012.

15. Khaled Aladwan Ramudu Bhanugopan Brian D'Netto. The effects of human resource management practices on employees' organisational commitment", International Journal of Organizational Analysis, Vol. 23 Iss 3 pp. $472-492,2015$.

16. Daifallah Olaimat, Bassam Awwad. Exploring the Relationship between Human Resource Practices and Employee Retention in the House of Representatives in Jordan. International Journal of Business and Social Science, Volume 8, Number 10, pp-178-185, ISSN 2219-1933 (Print), 2017.

17. Fiona Edgar, Alan Geare. HRM practice and employee attitudes: different measures - different results. Personnel Review, Vol. 34 Issue: 5, pp.534 549, https://doi.org/10.1108/00483480510612503, 2005.

18. Dr. Hazrina Ghazali, Nasyira Mohd Nasyuki, Oon Xiao Yi, Maisarah Binti Ishak. Human resource practices and employees' intention to stay in the kuala lumpur hotel industry. Accessed on 06-09-2018 at 11:35 am http://citeseerx.ist.psu.edu/viewdoc/download?doi=10.1.1.685.6037\&rep=rep1\&type=pdf 